УДК 378147

DOI:

Світлана Король, кандидат педагогічних наук, дочент кафедри практики та методики викладання іноземної мови Хмельницького національного університету

\title{
РОЗВИТОК ІНШОМОВНОЇ КОМУНІКАТИВНОЇ КОМПЕТЕНЦЇ̈ МАЙБУТНІХ ВЧИТЕЛІВ ІНОЗЕМНОЇ МОВИ ЗА ДОПОМОГОЮ МЕТОДУ ІНТЕЛЕКТ-КАРТ
}

У статті розкрито питання використання інтелект-карт задля розвитку іншомовної комунікативноі компетенщії під час підготовки майбутніх вчителів іноземної мови. Розглянуто ї̈ складові: лінгвістичну, соиіолінгвістичну та прагматичну компетениії. Доведено, щьо для ефективного розвитку всіх складових іншомовної комунікативної компетенції інтелект-карти стають гарною альтернативою для структурування та запам'ятовування навчального матеріалу, відображаючи прочеси багатовимірного мислення.

Ключові слова: іншомовна комунікативна компетенція; інтелект-карти; вчитель іноземної мови.

Jim. 9.

Svitlana Korol, Ph.D.(Pedagogy), Associate Professor of the Foreign Language Practice and Teaching Methodology Department Khmelnytskiy National University

\section{DEVELOPMENT OF FUTURE FOREIGN LANGUAGE TEACHERS' FOREIGN LANGUAGE COMMUNICATIVE COMPETENCE USING MIND MAPS}

The article deals with the issues of applying mind maps to develop foreign language communicative competence in training future foreign language teachers. According to the Common European Framework of Reference for Languages, Communicative Competence is divided into: Linguistic Competence: it refers to the ability of producing utterances in an efficient way in all its grammatical levels. It includes such competences as: lexical, grammatical, semantic, phonologic and orthographic competence. Sociolinguistic Competence: it is the ability of understanding and producing different utterances in different contexts of use where different factors play an important role, such as the relationship between participants, their situation, etc. Aspects to take into account here are social relationships markers, politeness norms, popular wisdom expressions, register differences, dialect and accent differences, etc. Pragmatic Competence: It makes reference to the ability of acting efficiently in a language taking into account grammatical forms and meaning to complete a text in different communicative events.

One of the effective methods for the development of foreign language communicative competence is Mind Mapping. The Mind Mapping process involves a unique combination of imagery, colour and visual-spatial arrangement which is proven to significantly improve recall when compared to conventional methods of notetaking and learning by rote. The mind map format is becoming an alternative to the traditional way of making notes, storing large quantities of educational information by a student for further use. Mind maps are graphically expressed processes of multidimensional thinking; they show the hierarchical interrelation of ideas. They're great for team use, as well as for all types of speech activity.

Application of mind maps is fully efficient for the development of foreign language communicative competence in training future foreign language teachers.

Keywords: mind mapping; foreign language communicative competence; foreign language teacher.

П остановка проблеми. Система освіти України має на меті підготовку висококваліфікованих вчителів іноземної мови, які володітимуть іншомовною комунікативною компетенцією і ефективно реалізовуватимуть свої знання та вміння під час своєї професійної діяльності. Підвищення якості професійно-педагогічної підготовки майбутніх вчителів іноземної мови зумовлює пошук сучасних форм, методів і засобів навчання майбутніх фахівців. Впровадження інноваційних технологій, що відповідають сучасним умовам, має стати пріоритетним чинником для забезпечення якісної підготовки вчителів іноземної мови. Зокрема, виникає потреба у дослідженні можливостей застосування технологій, які вже набули поширення закордоном. У контексті розвитку іншомовної комунікативної компетенції майбутніх вчителів іноземної мови привертає увагу метод інтелект-карт як ефективний спосіб структурування, візуалізації навчального матеріалу задля його полегшеного сприйняття i запам'ятовування.

Аналіз наукових джерел. Проблема формування іншомовної комунікативної компетенції цікавила вітчизняних та зарубіжних 


\section{РОЗВИТОК ІНШОМОВНОЇКОМУНІКАТИВНОЇ КОМПЕТЕНЦЇМАЙБУТНІХ ВЧИТЕЛІВ ІНОЗЕМНОӤ МОВИЗАДОПОМОГОЮМЕТОДУ ІНТЕЛЕКТ-КАРТ}

методистів І.О. Зимню, Ю.І. Пасова, Н.Ф. Бориско, Г.О.Китайгородську, О.Б. Тарнопольського, Р. Еліс (R. Ellis), M. Брамер (M. Brammer), Г. Каспар (G.Caspar), Н. Шміт (N. Schmitt). Проблематикою застосування інтелект-карт займалися вчені Т. Б'юзен (Т. Buzan), Б. Б'юзен (B. Buzan), Х. Мюллер (Н. Müller). Зокрема застосування методу інтелект-карт у навчанні іноземної мови досліджували вітчизняні науковці А. Гордєєва, С. Кулик, К. Перерва.

Метою статті $\epsilon$ дослідження застосування методу інтелект-карт для розвитку іншомовної комунікативної компетенції майбутніх вчителів іноземної мови.

Виклад основного матеріалу дослідження. Результат і якість професійно-педагогічної підготовки вчителя іноземної мови пов'язані з таким поняттям як “професійна компетентність”, складовою якої $є$ іншомовна комунікативна компетенція, тому її формування стає важливим чинником професійної успішності та конкурентоспроможності майбутнього фахівця.

Згідно “Загальноєвропейських Рекомендацій 3 мовної освіти”, комунікативна компетенція визначається як така, що складається з наступних трьох компетенцій - лінгвістичної, соціолінгвістичної та прагматичної.

Під лінгвістичною компетенцією розуміється знання і здатність використовувати формальні здібності, на основі яких можуть бути породжені і сформульовані добре оформлені, повнозначні висловлювання. Її складовими $є$ такі компетенції як:

- лексична компетенція - знання і здатність використовувати мовний словниковий запас складається 3 лексичних та граматичних елементів;

- граматична компетенція - знання і здатність користуватися граматичними ресурсами мови;

- семантична компетенція - здатність усвідомлювати і контролювати організацію змісту;

- фонологічна компетенція - знання та навички перцепції і продукції звукових одиниць мови та способів їх реалізації у певному контексті;

- орфографічна компетенція - знання і навички перцепції та продукції символів, 3 яких складаються письмові тексти;

- орфоепічна компетенція - знання правил написання; знання правил застосування письмових позначок.

Соціолінгвістична компетенція пов'язана зі знаннями та вміннями, необхідними для здійснення соціального аспекту використання мови. Зв'язок 3 лінгвістичними маркерами соціальних стосунків, правилами ввічливості, виразами народної мудрості, відмінностями у реєстрах мовлення, діалектами та акцентами.

Прагматична компетенція пов'язана iз знаннями користувача/учня про принципи, за якими висловлювання/повідомлення: організовуються, структуруються та укладаються (дискурсивна компетенція); використовуються для здійснення комунікативних функцій (функціональна компетенція); узгоджуються згідно 3 інтерактивними та трансактивними схемами (компетенція програмування мовлення) [3].

Формування іншомовної комунікативної компетенції входить до першочергових завдань процесу підготовки майбутніх вчителів іноземної мови. Сучасні реалії з одного боку диктують нові вимоги до цієї підготовки, з іншого відкривають широкий спектр сучасних методів та засобів навчання для реалізації поставлених завдань. Одним із методів, який можна успішно використовувати для розвитку іншомовної комунікативної компетенції майбутнього вчителя $\epsilon$ метод інтелект-карт (Mind-Map), автором якого вважається Тоні Б’юзен. У 1970 роках минулого століття він створив спосіб ведення записів, в яких використовуються лише ключові слова та образи. Науковець зробив акцент на візуалізації, переконуючи, що завдяки цьому полегшується процес сприйняття і запам'ятовування. Під час створення інтелект-карти активізуються творчі здібності людини, покращується ефективність мислення. Т. Бьюзен пояснює, що зображення привертають увагу до очей та мозку, запускаючи таким чином асоціації та допомагаючи пам'яті. При необхідності, додавання розміру та / або кольору перетворює слово на зображення. Т. Бьюзен зазначає, що запам'ятовування слів та речей відбувається через уяву і асоціацію, і якщо хтось уявляє людину, він не бачить слів, а бачить зображення. В ході своєї викладацької та письменницької діяльності Т. Бьюзен розробив широкий спектр додатків для концепції інтелектуальної карти, а також намагався зв'язати практичний метод з теорією людського мозку та сформулювати цілий ряд правил коректної побудови інтелект-карт [2].

Отже, для створення інтелект-карти потрібно обрати центральний образ, який символізує основну ідею або тему, що розміщується у центрі аркуша. Від нього відходять гілки першого рівня, на яких пишуться слова-асоціації, ключові поняття, що розкривають центральну ідею. При необхідності від гілок першого рівня відходять гілки другого рівня розукрупнення, що розкривають ідеї написані на гілках першого рівня. Рекомендується використовувати різні кольори 


\section{РОЗВИТОК ІНШОМОВНОЇ КОМУНІКАТИВНОЇ КОМПЕТЕНЦІЇМАЙБУТНІХ ВЧИТЕЛІВ ІНОЗЕМНОӤ МОВИЗАДОПОМОГОЮМЕТОДУ ІНТЕЛЕКТ-КАРТ}

для малювання карти, додавати малюнки, символи, що асоціюються 3 ключовими словами. За потреби використовуються стрілки, що з'єднують різні поняття на різних гілках. Навіть можна пронумерувати гілки і додати ореоли [7]. Остаточний вигляд інтелект-карти у кожного буде свій, але всі вони вирізнятися яскравістю, не шаблонністю, індивідуальністю, кумедністю малюнків тощо. Однак такі вільні та неординарні зображення, відгалуження та поєднання $є$ “графічним вираженням процесу радіантного мислення, природним продуктом діяльності людського мозку. Це потужний графічний метод, що надає універсальний ключ до вивільнення потенціалу, прихованого в мозку. Метод інтелектуальних карт може знайти застосування в будь-якій сфері життя, насамперед, де потрібно вдосконалювати інтелектуальний потенціал особистості, що досягається навчанням, або вирішувати різноманітні інтелектуальні завдання" [1].

Поняття "радіантне мислення" походить від терміну “радіант" - точка небозводу, з якої нібито виходять (внаслідок перспективи) видимі траєкторії метеорів одного метеорного потоку. Практично точки перетину численних шляхів [метеорів] зосереджені на невеликій площі, яка називається площею радіації, а центр цієї площі радіантом даного метеорного потоку” [5]. Таким же чином інтелектуальні асоціації створюють розгалужену мережу навколо центрального образу чи поняття, що дозволяє говорити про радіантне мислення.

Використання такого радіантного запису під час навчання стало гарною альтернативою ведення традиційних конспектів, які записуються нашвидкуруч, щоб не пропустити нічого зайвого, а потім в них важко знайти головне. Особливістю інтелект-карт $\epsilon$ те, що головне завжди в центрі уваги, а інші записи вирізняє стислість, влучність і яскравість, що дає змогу знаходити потрібне одразу, до того ж завжди є можливість внести доповнення або удосконалити попередні нотатки за допомогою кольорів чи інших символів. Тому інтелект-карти можна вважати кроком вперед на шляху прогресу від лінійного (одновимірного) через латеральне (двомірне) до радіантного (багатовимірному) мислення.

Як показує практика, інтелект-карти можуть знайти застосування у різних галузях знань, зокрема для вивчення іноземних мов. Тому вважаємо доцільним використання цього методу для розвитку іншомовної комунікативної компетенції, а саме для всіх компонентів її складу.

Так, розвиток лексичної компетенції потребує опрацювання лексичного матеріалу, в першу чергу запам'ятовування нових лексичних одиниць іноземної мови. Про поліпшення працездатності нашої пам'яті завдяки використанню візуальних елементів зазначає I. Свантессон (I. Svantesson), називаючи цей метод раціональним та креативним [9].

Для ефективного опанування лексики варто використовувати інтелект-карти, створюючи мережу навколо основного поняття, доповнюючи його символами і зображеннями, які впливають на наше сприйняття, адже наш мозок на $50 \%$ сприймає все на зір, тому візуалізація інформації $\epsilon$ надзвичайно потужним засобом для поповнення словникового складу іноземної мови. Створюючи інтелект-карту для окремої лексичної одиниці, вона виглядатиме як навчальна картка з різними виразами, синонімічними та антонімічними значеннями, граматичними формами цього слова. Інший вигляд матиме інтелект-карта, що створюється по закінченню вивчення лексичної теми, де карта охоплюватиме весь лексичний запас 3 вивченої теми. В такому випадку студентів можна долучати як до індивідуальної так і до групової роботи задля створення інтелекткарти як підсумку навчальної діяльності, розміщуючи на гілках все, що належить до основної теми. Таким чином відбувається систематизація вивченого матеріалу, виявлення прогалин у знаннях, усвідомлення і запам'ятовування. Створивши таку інтелекткарту пропонується не залишати їі просто на папері чи екрані монітору, а одразу підключати до усного мовлення. Це можуть бути різні ситуативні завдання із залученням інформації, представленої на карті.

Розвиток граматичної компетенції майбутніх вчителів іноземної мови є також важливим завданням у їх підготовці, адже їм потрібно не лише зрозуміти особливості граматики іншої мови, а й звернути увагу на ефективні методи засвоєння граматичного матеріалу, розвиваючи свою методичну компетенцію. Для граматики характерна системність та структурність, які краще за все зобразити на інтелект-карті, адже традиційні таблиці не можуть охопити весь обсяг граматичного явища.

Радіантна структура ідеально підходить для узагальнення та подання граматичних точок, спочатку узагальнено, а потім поступово, заглиблюючись у деталі. Вона відображає відносини і показує зв'язки різних пунктів граматики візуально. Більше того, можна використовувати різноманітні кольори, форми та значки, щоб зробити інтелектуальну карту більш легкою та зручною для запам’ятовування [4]. 


\section{РОЗВИТОК ІНШОМОВНОӤ КОМУНІКАТИВНОӤ КОМПЕТЕНЦІЇМАЙБУТНІХ ВЧИТЕЛІВ ІНОЗЕМНОӤ МОВИЗАДОПОМОГОЮМЕТОДУ ІНТЕЛЕКТ-КАРТ}

Комунікативна мовленнєва компетенція реалізується у виконанні різних видів мовленнєвої діяльності, і саме під час продуктивних видів мовлення таких як говоріння та письмо доцільно звернутись до створення інтелект карти. Так наприклад, монологічне мовлення передбачає підготовку розповіді або презентації за темою, тому за допомогою інтелект-карти можна спочатку генерувати ідеї до теми, структуруючи ïх логічно, доповнюючи візуальними зображеннями чи виділеннями, а потім використати ії̈ як вербальну опорудля відтворення загального змісту розповіді. Цінність використання інтелект-карти у тому, що під час процесу говоріння студент, спираючись на ключові моменти, самостійно будує речення, пов'язуючи з контекстом на відміну від того, коли розповідь повністю пишеться, а потім заучуються. Відсутність готових речень надає самостійності, спонукає до подальшого розвитку думок, розвиваючи таким чином живе мовлення.

Інтелект-карти варто також використовувати для підготовки до діалогічного мовлення, розміщуючи навколо теми дискусії свої думки, переконання, аргументи. Завдяки мозковому штурму вдається швидко зорієнтуватися в темі, не витрачаючи час на довгу писанину, генерувати ідеї та відповідно структурувати їх, що і полегшить відтворення думок під час дискусії.

Для ефективного писемного мовлення інтелект-карти використовуються як підготовча схема письмового твору чи переказу. Задля цього можна використовувати нумерацію розгалужених гілок, щоб зберегти цілісність та послідовність викладення змісту письмового завдання. Така візуалізація думок дозволяє їх зафіксувати на папері, не тільки, щоб не втратити слушну ідею, але й щоб від неї продукувати інші.

Рецептивні види діяльності такі як аудіювання та читання, які спрямовані на сприйняття інформації теж можна за бажанням опрацьовувати за допомогою інтелект-карт, занотовуючи ключові слова, словосполучення у формі розгалуженої мережі від основної теми, тим більше коли наступним завданням є відтворення почутого чи прочитаного.

Особливість розвиткуіншомовної комунікативної компетенції вчителя іноземної мови полягає в тому, що процес підготовки охоплює поглиблене вивчення дисциплін лінгвістичного спрямування: теоретичної та практичної фонетики, лексикології, практичної та теоретичної граматики, стилістики, лінгвокраїнознавства тощо. Використання інтелект-карт для оволодіння знаннями 3 цих дисциплін $є$ цілком виправданим, адже візуалізація та структурування значно полегшать сприйняття навчального матеріалу, дозволять розвинути власну стратегію навчання, де зміст інтелекткарти підпорядковуватиметься власним міркуванням і забезпечуватиме таким чином розуміння та запам'ятовування інформації. Інтелект-карти створені на "Практичному курсі англійської мови” та на “Лексикологіі” будуть відрізнятися своїм наповненням, проте відіграватимуть одну й ту важливу роль, спрямовану на розвиток лінгвістичної компетенції майбутнього фахівця. Особливістю методу використання інтелект-карт полягає у тому, що їх можна використовувати у будь якій сфері знань, пов' язаних з інтелектуальною діяльністю. Фахові дисципліни, зокрема лекційні курси потребують обробки великих об'ємів інформації і для того, щоб розвивалась іншомовна комунікативна компетенція потрібно опрацьовувати навчальний матеріал за спрямуванням інтелектуальних дій на структурування, систематизацію, конкретизацію, аналіз, синтез, порівняння, узагальнення, що дозволяють зреалізувати інтелект-карти.

Переваги використання інтелект-карт для розвитку іншомовної комунікативної компетенції полягають у тому, що зміст лінгвістичних дисциплін піддається структуруванню та класифікації; дозволяє створювати асоціативні зв'язки; його можна легко візуалізувати; спонукає до самостійного мислення; передбачає креативність мислення.

Для розвитку іншомовної комунікативної компетенції надзвичайно важливою є комунікація між мовцями, активна взаємодія під час усної мовленнєвої діяльності. Особливим позитивом роботи над створенням групової інтелект-карти, на думку К. Баєрл (C. Bayerl), є те, що цей процес дозволяє розвинути власні ідеї та фантазії завдяки імпульсам інших учасників. Науковець відносить інтелект-карти до креативних технологій та розкриває можливості інтелект-карт як інструменту мозкової діяльності, завдяки якому виникає загальна картина під час гри [6].

Відповідність структури інтелект-карт діяльності мозкових операцій підкреслює Б. Геммер (B. Gemmer), наголошуючи на тому, що застосування цього методу приносить задоволення, полегшує процес навчання і планування [8]. Таким чином зростатиме i мотивація до вивчення іноземної мови, що забезпечить успішний розвиток іншомовної комунікативної компетенції.

Висновки. Підсумовуючи все вище викладене, варто зазначити, що використання інтелект-карт як одного з методів розвитку 


\section{РОЗВИТОК ІНШОМОВНОЇКОМУНІКАТИВНОЇ КОМПЕТЕНЦІЇ МАЙБУТНІХ ВЧИТЕЛІВ ІНОЗЕМНОӤ МОВИЗА ДОПОМОГОЮМЕТОДУ ІНТЕЛЕКТ-КАРТ}

іншомовної комунікативної компетенції майбутніх вчителів іноземної мови є цілком доцільним. Лінгвістичні, соціолінгвістичні та прагматичні компетенції вчителя іноземної мови формуються і розвиваються на основі аналізу мовних явищ 3 фонетики, лексикології, фразеології, морфології, синтаксису, стилістики. Для кращого сприйняття та запам'ятовування матеріалу 3 цих лінгвістичних дисциплін виправданим $\epsilon$ використання методу інтелект-карт, що допомагає ефективно структурувати і аналізувати навчальний матеріал, креативно мислити, генерувати ідеї, запам'ятовувати та слугувати опорою для відновлення інформації. Отже, лінгводидактичний потенціал методу інтелекткарт має велике значення для розвитку іншомовної комунікативної компетенції майбутніх вчителів іноземної мови і тому він може бути впровадженим у процес підготовки вчителів іноземної мови на багатьох навчальних дисциплінах.

Перспективи подальших розвідок у даному напрямку. У час стрімкого розвитку технічних, інформаційно-комунікаційних засобів 3'явилась можливість використовувати їх у створенні інтелект-карт, тому наступним кроком вважаємо за потрібне дослідити та впровадити в процес викладання створення інтелект-карт за допомогою інтернет-технологій.

\section{ЛІТЕРАТУРА}

1. Алексеева И. Ю. Интеллект и технологи. М.: Проспект, 2017. 96 с.

2. Бьюзен Т., Бьюзен Б. Супермышление. Минск: Попурри, 2003.304 c.

3. Загальноєвропейські Рекомендації з мовної освіти: вивчення, викладання, оцінювання / Науковий редактор українського видання доктор пед. наук, проф. С. Ю. Ніколаєва. К.: Ленвіт, 2003. $273 \mathrm{c}$.

4. Иванов П. П. Использование интеллекткарт в учебном процессе. Информатика и образование. 2012. № 3. С. 68-71.
5. Словник української мови в 11 томах. електрон. версія журн. 1977. T. 8. C. 429. URL: http://sum.in.ua/s/radiant (дата звернення: 05.02.2019)

6. Bayerl C. M. 30 Minuten für Kreativitätstechniken. Gabal; Auflage: 2. 2005. $80 \mathrm{~S}$.

7. Buzan T. The Mind map book. USA: Dutton, 1994. $322 \mathrm{p}$.

8. Gemmer B. Mind Mapping - fit in 30 Minuten. Gabal; Auflage: 4. 2001. 62 S.

9. Svantesson I. Mind Mapping und Gedächtnistraining. Gabal; Auflage: 7. 2004. 142 S.

\section{REFERENCES}

1. Alekseeva, I. Yu. (2017). Intellekt i tehnologii [Intellect and technology]. Moskov: Prospekt, 96 p. [in Russian].

2. Buzan, T. \& Buzan, B. (2003). Supermyishlenie [Super thinking]. Minsk: Popurri, 304 p. [in Russian].

3. Zahalnoyevropeyski rekomendatsiyi z movnoyi osvity: vyvchennya, vykladannya, otsinyuvannya (2003). [The Common European Framework of Reference for Languages: Learning, Teaching, Assessment]. (Ed.). S. Y. Nikolayeva. Kyiv, Lenvit, 273 p. [in Ukrainian].

4. Ivanov, P.P. (2012). Ispolzovanie intellekt-kart $\mathrm{v}$ uchebnom protsesse [The use of mind maps in the learning process]. Informatics and education. No. 3,pp. 68-71. [in Russian].

5. Slovnyk ukrayinskoyi movy (1977). [Dictionary of the Ukrainian language]. in 11 volumes. Vol. 8. p. 429. [in Ukrainian].

6. Bayerl, C. M. (2005). 30 Minuten für Kreativitätstechniken [30 minutes for creative technology]. Gabal; Auflage: 2, 80 p. [in German].

7. Buzan, T. (1994). The Mind map book. USA: Dutton, 322 p. [in English].

8. Gemmer, B.(2001). Mind Mapping - fit in 30 Minuten [Mind Mapping - fit in three minutes] Gabal; Auflage: 4, 62 p. [in German].

9. Svantesson, I. (2004). Mind Mapping und Gedächtnistraining [Memory training]. Gabal; Auflage: 7, 142 p. [in German].

Стаття надійшла до редакції 12.02.2019

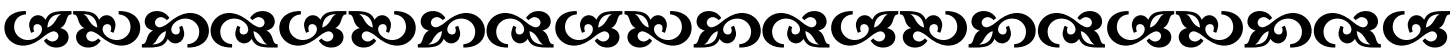

“Dо гідної мети немає коротких шлахів”.

Телен Келлер

американська письменниця

“Знання - це сқарб, яқий всюди слідує за тим, хто ним володіє”.

Китайське прислів'я

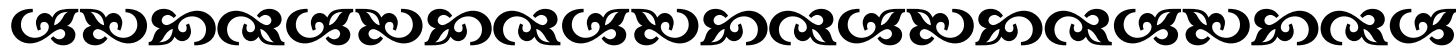

Молодь і ринок №3 (170), 2019 